« Do academic laboratories correspond to scientific communities ? Evidence from a large European university »

$\underline{\text { Auteurs }}$

Rachel LÉVY

Paul MULLER

Document de travail $\mathrm{n}^{\circ} \mathbf{2 0 0 6 - 1 5}$

Mai 2006

Faculté des sciences économiques et de gestion Pôle européen de gestion et d'économie (PEGE) 61 avenue de la Forêt Noire F-67085 Strasbourg Cedex

Secrétariat du BETA Christine Demange Tél. : (33) 0390242069 Fax : (33) 0390242070 demange@cournot.u-strasbg.fr http://cournot.u-strasbg.fr/beta 


\title{
Do academic laboratories correspond to scientific communities? Evidence from a large European university
}

Rachel Levy*, Paul Muller ${ }^{+}$

\begin{abstract}
Although acknowledged as central in the economic literature, the issue of intra academic collaboration has been, insofar, relatively overlooked. This paper fills this gap by stressing the importance of communities in academic research. By analysing the publication behavior of researchers from a large European scientific university, we argue that in certain cases, the community level constitutes a relevant level for analysing the collaborative nature of scientific investigation. Indeed, the reality of research collaborations doesn't always fit the institutional division of academic work provided by laboratories.
\end{abstract}

Keywords: Economics of Science, Knowledge Intensive Communities, Academic Collaborations, Social Network Analysis.

JEL Classification: L31 - O31 - O32.

- BETA-CEREQ, University Louis Pasteur, 61 Avenue de la Forêt Noire, 67085 Strasbourg, email : levy@cournot.u-strasbg.fr

+ Institut National de la Recherche Agronomique, SICOMOR, Chemin de Borde-Rouge. 31326 Castanet Tolosan. Email : Paul.Muller@toulouse.inra.fr 


\section{Do academic laboratories correspond to scientific communities? Evidence from a large European university}

Rachel Levy`, Paul Muller ${ }^{+}$

\section{Introduction}

Recent years have seen an important increase in the number of quantitative studies of scientific production. The common aim of those contributions has been to describe the determinants and factors influencing scientific production. At the individual level, numerous effects were inspected such as age (Diamond, 1986, Levin and Stephan, 1991), cohort (Weiss and Lillard, 1982) or gender (Stephan, 1998). At a more collective level, the focus was more particularly put on the laboratory level of analysis. Were notably evaluated the reciprocal influence of individual characteristics and the reputation of research laboratories (Allison and Long, 1990, Long and McGinnis, 1981), research organization (Carayol and Matt, 2004a and b) or multidisciplinarity (Carayol and Nguyen Thi, 2004).

Strangely, although collaboration is commonly acknowledged as an important factor (cf. Dasgupta and David, 1994, Katz and Martin, 1997) influencing scientific knowledge production, very few contributions, and particularly in economics, explicitly analysed the issues linked to collaboration within the academic sphere (at the notable exception of Knorr Cetina, 1981 and 1999). For instance, past contributions failed to take into account the fact that collective processes of knowledge production involves a big deal of exchanges among individuals through socialization and the confrontation of different (and, sometimes, conflicting) ideas and perspectives. This lack in the literature is all the more strange that numerous recent contributions (Brown and Duguid, 1991, Amin and Cohendet, 2000) highlighted the role of collaboration for the production and diffusion of knowledge by pointing out the importance of communities in a knowledge economy. The argument frequently put forward is that communities lie at the core of collective learning and knowledge production processes (see, e.g. Cowan and Jonard, 2003) since they rely on a constant exchange of knowledge and information.

\footnotetext{
- BETA-CEREQ, University Louis Pasteur, 61 Avenue de la Forêt Noire, 67085 Strasbourg, email: levy@cournot.u-strasbg.fr

${ }^{+}$Institut National de la Recherche Agronomique, SICOMOR, Chemin de Borde-Rouge. 31326 Castanet Tolosan. Email : Paul.Muller@toulouse.inra.fr

This work exploits an original database covering the whole academic activity at University Louis Pasteur. This database was developed by a team of researchers at BETA. We are gratefully to all members of the team for having contributed to its construction.
} 
This contribution aims at tackling several theoretical issues by:

1. Presenting a method for identifying those scientific communities. This identification method is based on the tools provided by social networks analysis.

2. Accounting for the diversity in the organization of scientific knowledge production by stressing the coexistence of different types of research groups that we could call as "communities".

In addressing those questions, this paper attempts to connect two streams of literatures: the literature on the economics of science and the literature on knowledge intensive communities. An important result of our contribution is that the organizational frontiers of laboratories don't, in most cases, match with the frontiers of these research groups.

The remainder of this article is organized as follows. In the next section, we will expose the basic concepts used in this paper. We will present a survey of contributions on academic research production which aims to stress the limits of existing literature. In a third section, we will expose the methodology for identifying academic "communities". This methodology will then be applied to the study of the copublication network of a large European scientific university: the University Louis Pasteur in Strasbourg. In order to do so, we will make use of an original database built by members of the BETA covering the whole academic activity of that university for the last decade. In a fourth section, we will detail the results obtained. We will notably show that the reality of collaboration doesn't, in most cases, match the institutional division provided by laboratories.

\section{Literature survey}

The aim of this paper is to explore the collective nature of the production of academic knowledge. So we will briefly present a survey of the literature existing in this domain in order to explore issues that have been insofar overlooked. Our aim is not to offer an exhaustive description of this literature. Rather, we would like to sketch an overview of the state of the art and to briefly present its main results.

As pointed out by several scholars (e.g. Merton, 1957, David, 1998), an important factor at the root of current "open science" (contrasting with the "realm of technology") lies in the regime of priority. This norm of behaviour aims at providing scientists with the incentives to disclose knowledge. Indeed scientific knowledge could be viewed as a public good: useful for 
the whole society, but with few incentive to be produced because of its properties of non rivalry and non exclusivity. This justifies an incentive system to produce this type of knowledge. This has motived a certain number of authors to analyse this incentive system by studying the determinants of scientific knowledge production. One determinant is the rules of priority in the Republic of Science (Dasgupta and David, 1994) and the need for acknowledgement by peers. It states that, once disclosed and validated by peers, only the scientists at the origin of the newly produced knowledge have the right to enjoy the gains associated with it (Dasgupta and David, 1994). Those gains may take several forms. They may be in terms of peer recognition (Merton, 1968) or they may be financial. Still, another factor which has been less highlighted lies in the existence of intrinsic motivations associated with the pursuit of academic research. Those motivations consist in the pleasure derived from puzzle solving (Stephan, 1996) or, more selfishly, with the pride inherited from being the first to make a given discovery.

More generally, economists of science have been mainly concerned with an exploration of the determinants and the organization of scientific production. They developed their argument at two levels of analysis: at the individual level and at the laboratory level.

So, the analysis of the determinants of scientific production at the individual level has benefited from a long lasting interest from sociologist and economists of science. Several factors and phenomena were pointed out, such as the reward structure of science (e.g. with the existence of the system of academic prizes) and the existence of more intrinsic motivations, the raising of inequalities among scientists or age.

A second and related issue tackled by sociologists of science was dealing with the analysis of the development of inequalities in scientific production among researchers. Several researchers pinpointed that the distribution of scientific production was highly skewed by following a Lotka's Law (e.g. de Solla Price, 1963, Cole and Cole, 1967, David, 1994). More precisely, it was found that less than six percent of scientists published almost fifty percent of all papers. The explanation for this observation lied in the existence of accumulative advantage. It consists in the interaction between two retroactive loops involving recognition and the acquisition of resources for research. On the one hand, recognized scientists are more motivated for the pursuit of their research, thus enhancing their reputation. On the other hand, high levels of reputation facilitate the access to complementary resources which will increase the productivity and the quality of the research (Allison and Steward, 1974). 
Another factor affecting individual productivity was identified with age. Some of the scientists interested in this issue built several types of models aiming to explain differences in scientific production along with the age of a scientist. By adapting a model of life-cycle human capital investment, Diamond (1986) found a negative relationship between productivity and age for mathematicians at the University of Berkeley. By contrast, in a longitudinal study of PhD scientist, Stephan and Levin (1991) found that, in most of the fields of enquiry, research productivity increases with age to reach a peak at mid-career and, then, decreases. This result was then confirmed in several studies such as in Turner and Mairesse (2002).

Those studies, by mainly focusing on individual determinants of scientific production fail to grasp several important factors linked to the environment. At a more intermediary level, some empirical studies led in the USA pinpointed the importance of the research environment and the existence of a relatively strong positive relationship between productivity and quality at the individual level and scientific prestige at the department level. This gave rise to the study of two alternative hypothesis formulated by Allison and Long (1990): do good departments encourage and facilitate individual research productivity or do they attract the best and most promising scientists, thus inducing a strong selection effect? Those authors found that researchers joining prestigious departments tended to increase their research productivity while the fact of joining less prestigious centres induced decreases in the researchers' productivity, thus lending weight to the former hypothesis. This conclusion corroborated the result obtained by Long and McGinnis (1981).

In complement to this analysis at the individual level, some authors studied scientific productivity at a more collective level, by considering that scientific research is a collective and collaborative process. Indeed, in their study of the research organization at the University Louis Pasteur of Strasbourg, Carayol and Matt (2004a) built a typology of research laboratories along four dimensions: the size of the laboratory (this variable is associated with the scale issue emphasised by Bonaccorsi and Daraio (2002)), research intensity (corresponding to the trade-off operated by researchers between research and teaching activities), the degree of performance (in terms of publication productivities), and the degree of openness of the lab (towards the integration of young or international researchers or towards the industry). This allowed them to differentiate between five classes of research labs: 1) research intensive laboratories, 2) teaching oriented labs in the fields of social and 
human sciences, 3) non research-intensive and industry oriented labs, 4) elite research intensive labs and 5) large laboratories.

Nevertheless, if these studies analyse the scientific research as a collective process, it supposes a correspondence between this collective level and the official level defined by national institutions: that is to say the official laboratories or units of research. However, if scientific production is a collective process; it has not been tested in the literature whether the laboratories level is a relevant level level where collective scientific activities takes place. By contrast, this analytical problem of determining the pertinent level of collective knowledge production has been addressed (more at the level of the firm) in different streams of literature such as the development of open source software (Muller, 2004) or the knowledge based theory of the firm (e.g. Cohendet and Llerena, 2003). All those streams of literature stress the importance of knowledge intensive communities for collective learning and knowledge creation processes.

\section{Social network analysis}

After having given an overview of the basic concepts underlying this paper, we will, in next sections, justify the relevance of the concept of community in addressing the issue of academic collaboration. In order to do so, we will analyse the network of copublications of researchers from the University Louis Pasteur.

We have to restrict our analysis of scientific collaboration to copublication. This choice is motivated by several factors. First, contrary to others indicator of collaboration (research contract, European framework contracts, research scholarships...), copublication is an indicator of individual collaborations (Katz and Martin, 1997). Furthermore, since it widely acknowledged that a lot of interactions are informal, it becomes rapidly difficult to provide a reliable methodology for assessing informal interactions at the level of the university. Even though publication could involve a bias in the analysis of scientific production, it works as a "second best" indicator in the same way as the patent is viewed as a second best indicator for collaboration among industrial firms (Adams and Grilliches, 1996).

\section{Methodology}

In order to analysis the network of copublications of these researchers, we will use a methodology based on social networks analysis. The first phase of the work consists in 
building up the social network accounting for collaboration relationships between academic researchers. A social network can be defined in the following way:

"A social network is a set of people or groups each of which has connections of some kind to some or all of the others. In the language of social network analysis, the people or groups are called "actors" and the connections "ties"." (Newman, 2001, p.1).

According to this definition, we could confirm that this methodology could be useful to answer our research question, indeed, in our case, actors correspond to permanent researchers from ULP while the connections between them are approximated by publications. The choice of co-publications is motivated by the fact that it constitutes a rather objective and tractable measure of a collaboration involving several researchers ${ }^{1}$.

Once the social network of scientific coauthorships built, the second step of the methodology consists in isolating scientific groups. In order to do so, we exploit the differential in ties densities existing within and between those groups of co-authors. Indeed, as pointed out by Newman and Girvan (2004), a property shared by many social networks, is that they can be divided into groups within which the ties are dense but between which they are sparser. Those groups correspond to clusters within which the density of ties is much higher than between them.

A method for stressing the communitarian structure of a social network is provided by its decomposition through hierarchical clustering (see Johnson, 1967 for the original exposition of the methodology or Newman, 2004, Girvan and Newman, 2002 for alternative methods based on betweeness). The logic underlying the hierarchical clustering methodology for exhibiting clusters within a network is to remove the ties located between those clusters. Those ties feature a particular property within the social network since it is assumed that few of them bind different clusters. Hence the main challenge is to identify those particular links. The identification issue is solved by calculating a similarity measure for each node.

In the UCINET software, the measure of similarity is a function of the geodesic distance between nodes ${ }^{2}$. The logic underlying this reasoning is the following: since clusters are

\footnotetext{
${ }^{1}$ As underlined by Katz and Martin (1997), copublication only constitutes an imperfect measure of a scientific collaboration since it doesn't document about the conditions underlying a collaboration those authors did establish. In this way, are considered as collaborators "(a) those who work together on the research project throughout its duration or for a large part of it, or who make frequent or substantial contribution; (b) those whose names or posts appear in the original research proposal; (c) those responsible for one or more of the main elements of the research" (p. 7)

${ }^{2}$ The geodesic distance between two nodes A and B is defined as the minimum number of nodes necessary to join $\mathrm{A}$ and $\mathrm{B}$.
} 
assumed to be very dense, reaching any other node of the same cluster requires to pass through very few nodes. Thus, the geodesic distance between two nodes belonging to the same cluster is very low. In this respect, nodes of a same cluster can be considered as similar. By contrast, two nodes of different clusters are connected by a low number of paths. It then becomes more difficult to find a path joining two nodes belonging to different clusters and passing through a few nodes. Then, the distance between them is likely to be much higher. It follows that those nodes are considered as dissimilar (Wasserman and Faust, 1994).

Therefore the methodology underlying hierarchical clustering aims at decomposing the graph into groups of nodes within which the distances between them are low and between which the distances are high. The methodology is iterative since it groups nodes according to increasing distances. The algorithm, following the methodology developed by Johnson (1967), proceeds as follows (Borgatti, 1994):

0. Before the start of the algorithm, are computed distances between nodes of the graph.

1. The algorithm starts by assigning each node to its own cluster, so that if you have $\mathrm{N}$ items, you now have $\mathrm{N}$ clusters, each containing just one item. Let the distances between the clusters equal the distances between the items they contain.

2. Find the closest pair of clusters and merge them into a single cluster, so that now you have one less cluster.

3. Compute distances between the new cluster and each of the old clusters.

4. The algorithm repeats steps 2 and 3.

Apart from distance, the hierarchical clustering methodology can be applied following other criteria. An other popular criterion is given by the calculation of correlations among nodes (Wasserman and Faust, 1994). This criterion is based on the calculation of correlation coefficients among nodes which might be described as the capacity of two actors to be tied with the same set of actors (Degenne and Forsé, 1994). However, as pointed out by Wasserman and Faust (1994), the results of those two methodologies are identical.

In our case, the end of the algorithm is determined by the following trade-off. On the one hand, we wish to obtain the most precise decomposition of the research network by identifying the most numerous clusters. On the other hand, the division has to keep a certain 
degree of meaningfulness: clusters have to be large enough to show the collaborative nature of academic research. In our cases we have stopped the clustering after the fifth iteration: this level allow us to obtain relatively dense cluster and separated by a maximum of 3 links between clusters. Horever, we have also decided to stop the clustering after the fifth iteration in order to obtain cluster with an average size of 15,02 that is not far from the average size of the laboratories which is equal to 17,47 .

\section{Data}

The university under analysis is the University Louis Pasteur (or ULP). ULP is a French university based in Strasbourg. ULP is internationally acknowledged for its academic excellence since it currently hosts 1 Nobel Prize in Chemistry (J-M Lehn in 1987) and other scientific prizes, is ranked $92^{\text {nd }}$ in the last (2005) ranking from the University of Shanghai (Together with 3 Parisian universities, it is one of the only French university in the "top-100",3 and was ranked $11^{\text {th }}$ among European Universities in terms of scientific impact by the Third Report on Science and Technology Indicators (2003). The University Louis Pasteur is of relative big size since it hosts about 18000 students and 1500 researchers. Moreover, it covers all scientific fields: mathematics, physics, chemistry, earth and universe sciences, engineering sciences and ULP is widely acknowledged for its specialization in life sciences and chemistry. Finally, apart from "hard sciences", ULP covers social sciences such as economics and management, geography and psychology.

The database we are using in this paper was built by a research team of BETA. It gives an account of the university's scientific activity. It gathers research inputs and outputs of the university. In this paper, we are using 3 components of this ULP database: the list of researchers of the university, their laboratories and the publications that theses researchers have made. The permanent researchers and research laboratories databases are built upon four-years contractual affiliation rounds (contrats quadriennaux). For those rounds, all laboratories have to produce a document summarizing its research activity for the last four years and a forecast of its research activity for the four next years. This document notably includes the list of permanent researchers affiliated to the laboratory. Our analysis is based on the 2000 round and counts 1433 permanent researchers working in 82 research labs. The researchers' database gives information such as researchers' name, sex, birthday, position, discipline, the research organism (university, CNRS, INSERM, INRA) they are affiliated to

\footnotetext{
${ }^{3}$ Only 4 french university are included in this ranking which takes into account the number of Nobel and Field Prizes, the number of articles in the reviews Science and Nature, the number of the most cited scientists in 21 disciplines, the number of articles included in the SCI database and the size of the university.
} 
and the research units they work for. The laboratory database includes information such as the main disciplines and research interest of the lab, its institutional affiliation (affiliated or associated to the University, CNRS, INSERM, INRA) as well as the number of permanent researchers, $\mathrm{PhD}$ students, post-doctoral students, etc...

For the present study, we only selected papers authored by the 1433 permanent researchers working at the ULP in 2000 and published between 1996 and 2000. The publications were extracted from the Science Citation Index and Social Science Citation Index databases according to the name and initials of the researcher complemented by a request localizing at least one author in a site of the ULP ${ }^{4}$. Finally we obtain a list of 7840 articles published or co-published by ULP authors. That figure correspond to 17541 publications if consider the count of publications made between different authors of the university.

\section{Results}

The goal of this section is to provide the first results of the analysis of the social network of ULP researchers through hierarchical clustering. The network analysis and the graphs were made using the network analysis program UCINET (Borgatti et al., 2002).

The network we generated includes 1097 researchers who published with a minimum of one other author of ULP what we could compare to the 1443 researchers listed in the original database. This gap accounting for about $24 \%$ of the researchers can be explained globally by the fact that we included in our analysis only publications in which ULP researchers collaborated with other ULP researchers. Hence, were not counted publications involving several authors among which only one ULP researcher.

Globally, the principal results of this study is that we remark an apparent mismatching between collaboration clusters accounting for the collaborative character of scientific research, and the administrative borders of the laboratories. Apart from the "canonical" case in which the frontiers of the laboratory matches the frontiers of the cluster, numerous other cases may appear, among which the case of laboratories regrouping several clusters, or the case in which a research lab spreads over several clusters. In the same way, we could find clusters regrouping different laboratories, or splitting between different labs. So, a first conclusion to be stressed is that the study of research collaborations must pay a specific

\footnotetext{
${ }^{4}$ The request correspond to "strasbourg* or ulp or illkirch* or schiltigheim or wissembourg or cronenbourg or colmar or haguenau" and name and initials*
} 
attention to its communitarian dimension. In the remainder of this section, we will, in a first part, inspect in more details the division of academic work by establishing a typology of those clusters and try to establish their communitarian characteristics. In a second part, we will focus more specifically on research laboratories with respect to the division of collaboration network into distinct cluster.

\section{Characterization of scientific clusters}

\section{Description of clusters.}

Community identification through hierarchical clustering gave rise to the isolation and the identification of 73 clusters (cf. table 1). Those clusters are grouped into 7 categories (table 1) and that could be defined in the following way.

Clusters of type $\mathrm{C} 1$ correspond to individuals who are considered as intermediaries since they bind together several clusters. More particularly, all those "isolated researchers" connect big clusters (of the $\mathrm{C} 5$ type) with other types of clusters (C2, C3, C4, C6 or C7). They can act as "go-between" in the sense that they can facilitate the interaction between two different clusters as they allow to decrease the related costs by mitigating the risk of hold-up (Nooteboom, 1999). These individuals could be qualified as mediators allowing a transfer of knowledge of two groups of persons with different cognitive capacities: these mediators could decrease the distance between theses groups (Levy, 2005).

Clusters of types C2 and C3 represent binoms or trinoms. Those types of clusters correspond to the case in which two or three researchers collaborate intensively together while collaborating in a more limited extent with other researchers. More particularly to those clusters, one could draw a distinction between binoms or trinoms belonging to the same research laboratories and binoms or trinoms spreading over several research laboratories..

C4 and C5 clusters gather scientists from the same research laboratory. Those clusters can either correspond to research laboratories (as in the case of $\mathrm{C} 4$ clusters) or form a subpart of a laboratory (as for C5 clusters). The relevance of the distinction between C4 and C5 clusters lies in the fact that research labs are commonly split between several research teams corresponding to different research interests. These two groups of clusters are of relatively varied sizes, counting from 4 to more than 40 members. Researchers in those clusters perform rather high publication rates, $\mathrm{C} 5$ scientists being, on average, even more prolific than $\mathrm{C} 4$ ones. However, disparities between the publication rates in $\mathrm{C} 5$ clusters are much higher than for $\mathrm{C} 4$ scientists. 
C6 clusters correspond to "big" clusters grouping several research laboratories. As indicated, those clusters group numerous researchers who are tightly connected to each other. Researchers belonging to C6 clusters enjoy high publication productivities, disparities in productivities being relatively low. The big size, together with the high density of the cluster indicates high collaboration rates among researchers.

Finally, C7 clusters are clusters binding together several laboratories. Typically, they involve different sub-groups from several research laboratories working together in the same cluster. This contrasts with $\mathrm{C} 7$ clusters in which individuals tend to collaborate with researchers from other labs and from other disciplines: theses clusters spread over several research labs.

$\mathrm{C} 4$ and $\mathrm{C} 5$ clusters exhibit a very low degree of interdisciplinarity, thus indicating that members of the same research lab strongly collaborate with peers sharing the same discipline, they correspond to subgroups within research labs. In this case too, researchers from the same lab appear to give priority to collaborations with individuals of the same discipline and who potentially share common research interests. Excepted one cluster, all clusters in this category regroup a majority of physicists. By contrast, in both $\mathrm{C} 6$ and $\mathrm{C} 7$ clusters researchers in life science are well represented even though the results are less clear than in the case of $\mathrm{C} 4$ and C5 clusters. Therefore, we could suppose that the heterogeneity levels encountered in C6 and C7 clusters is linked to the specific work practices in life sciences. At the opposite, work practices among physicists seem to be more disciplinary and to take place within the frontiers of the lab. 
Table 1: Typology of clusters: 73 clusters gathered in 7 categories.

\begin{tabular}{|c|c|c|c|c|c|c|}
\hline $\begin{array}{l}\text { Type } \\
\text { of } \\
\text { clusters }\end{array}$ & Characterisation & $\begin{array}{l}\text { Number } \\
\text { of } \\
\text { clusters } \\
\text { in this } \\
\text { group }\end{array}$ & $\begin{array}{l}\text { Number of } \\
\text { researchers } \\
\text { in this } \\
\text { group }\end{array}$ & $\begin{array}{l}\text { Average } \\
\text { number of } \\
\text { researchers } \\
\text { (std. dev.) }\end{array}$ & $\begin{array}{l}\text { Average number } \\
\text { of publications/ } \\
\text { researchers (std. } \\
\text { dev.) }\end{array}$ & $\begin{array}{l}\text { Average degree of } \\
\text { multidisciplinarity } \\
\text { (std. dev) }\end{array}$ \\
\hline $\mathrm{C} 1$ & \begin{tabular}{ll}
\multicolumn{2}{l}{ Intermediaries: } \\
researcher & linking \\
together & several \\
clusters &
\end{tabular} & 5 & 5 & - & $5.4(9.29)$ & $-(-)$ \\
\hline $\mathrm{C} 2$ & $\begin{array}{l}\text { Binoms or trinoms } \\
\text { ( } 2 \text { or } 3 \text { researchers } \\
\text { bound together })- \\
\text { from the same } \\
\text { laboratory }\end{array}$ & 25 & 53 & $2.12(0.33)$ & $5.89(4.08)$ & $0.11(0.26)$ \\
\hline $\mathrm{C} 3$ & $\begin{array}{l}\text { Binoms or trinoms } \\
\text { ( } 2 \text { or } 3 \text { researchers } \\
\text { bound together) - } \\
\text { from several } \\
\text { laboratories }\end{array}$ & 23 & 54 & $2.35(0.49)$ & $4.85(3.82)$ & $0.59(0.34)$ \\
\hline $\mathrm{C} 4$ & $\begin{array}{l}\text { Clusters } \\
\text { corresponding to a } \\
\text { research laboratory }\end{array}$ & 3 & 60 & $20(17.09)$ & $10.42(2.05)$ & $0.87(0.65)$ \\
\hline $\mathrm{C} 5$ & $\begin{array}{l}\text { Clusters forming a } \\
\text { subpart of a } \\
\text { research laboratory }\end{array}$ & 4 & 74 & $18.5(15.42)$ & $14.09(14.08)$ & $0.44(0.38)$ \\
\hline C6 & $\begin{array}{lr}\text { "big" } & \text { clusters } \\
\text { grouping } & \text { several } \\
\text { research } & \\
\text { laboratories } & \\
\end{array}$ & 2 & 621 & $\begin{array}{l}310.5 \\
(225.57)\end{array}$ & $17.18(2.07)$ & $1.32(0.05)$ \\
\hline $\mathrm{C} 7$ & $\begin{array}{lr}\text { Clusters } & \text { spreading } \\
\text { over reveral } \\
\text { laboratories } \quad \text { (but } \\
\text { which doesn't } \\
\text { group them) }\end{array}$ & 11 & 230 & $\begin{array}{l}20.91 \\
(14.63)\end{array}$ & $12.43(4.80)$ & $0.97(0.36)$ \\
\hline
\end{tabular}

\section{Characterization of research laboratories}

\section{Typology of research laboratories}

In the former paragraphs, we identified and stressed a typology of clusters according to several criteria such as their size (by drawing a distinction between isolated scientists, binoms and trinoms on the one hand, and bigger clusters on the other) and status with respect to research laboratories. In this part, we will propose a typology of research labs gathered into 6 groups that could be described by the following characteristics (cf. table 2):

\footnotetext{
${ }^{5}$ We compute the degree of interdisciplinarity of cluster $j$ as follows:

multidisc $_{j}=-\sum_{i \in L_{i}} \frac{n_{i j}}{N_{j}} \cdot \log \left(\frac{n_{i j}}{N_{j}}\right)$

Where $n_{i j}$ corresponds to the number of individuals from discipline $i$ who belong to cluster $j, N_{j}$, the population of cluster $j$, and $L_{j}$ the set of disciplines in cluster $j$. High degrees of multidisciplinarity are characterized by high value of the index. This definition is adapted from the measure of entropy developed in Carayol and Matt (2004b) and Carayol and Nguyen Thi (2004).
} 
A laboratory of the first type (L1) regroups researchers that are not used to copublish with others ULP's researcher.

L2 labs gather laboratories regrouping several clusters: we could suppose that this clusters constitute small teams of large laboratories, indeed as shown in table 2, the average size of this group of laboratories in a size of 56 researchers that may collaborate in small subgroups of between 10 and 20 researchers.

L3 and L4 laboratories are laboratories in which researchers work in the same cluster. The distinction between those two classes of labs relies on the fact that for L3 labs the borders of a cluster roughly correspond to a lab while L4 labs are integrated to wider clusters grouping several labs. In those two cases (and in particular for L3 labs), we could observe a correspondence between the administrative borders of the labs and the actual organisation of the work inside the university. We could also note that logically, those labs are smaller than the laboratories of the second group.

Finally, L5 and L6 laboratories spread over several cluster. L5 and L6 labs differentiate by their size: L5 labs are considered as "small" since they count less than 24 members while L6 labs have more than 24 researchers. These laboratories correspond to an administrative organisation that is very different from the actual way of collaborating among researchers of these labs.

Table 2: Typology of laboratories: 82 laboratories gathered in 6 categories

\begin{tabular}{|l|l|l|l|l|}
\hline $\begin{array}{l}\text { Type } \\
\text { laboratories }\end{array}$ & Characterisation & $\begin{array}{l}\text { Number of } \\
\text { laboratories of the } \\
\text { category }\end{array}$ & $\begin{array}{l}\text { Number of } \\
\text { researchers of the } \\
\text { category }\end{array}$ & $\begin{array}{l}\text { Average number of } \\
\text { researchers (std. } \\
\text { dev.) }\end{array}$ \\
\hline L1 & $\begin{array}{l}\text { Laboratories which not } \\
\text { publish inside ULP }\end{array}$ & 13 & 271 & $20.92(19.01)$ \\
\hline L2 & $\begin{array}{l}\text { Laboratories regrouping } \\
\text { several clusters }\end{array}$ & 2 & 113 & $56.5(27.58)$ \\
\hline L3 & $\begin{array}{l}\text { Laboratories } \\
\text { corresponding to clusters }\end{array}$ & 23 & 203 & $8.83(4.03)$ \\
\hline L4 & $\begin{array}{l}\text { Laboratories being part of } \\
\text { a cluster }\end{array}$ & 3 & 127 & $42.33(35.64)$ \\
\hline L5 & $\begin{array}{l}\text { Smal (<24 researchers) } \\
\text { laboratory spreading over } \\
\text { several clusters }\end{array}$ & 31 & 341 & $11(4.52)$ \\
\hline L6 & $\begin{array}{l}\text { Big ( } \geq 24 \text { researchers) } \\
\text { laboratory spreading over } \\
\text { several clusters }\end{array}$ & 10 & 3777 & $37.7(17.85)$ \\
\hline
\end{tabular}

In all types of laboratories (excepted for L1 labs), the majority of researchers actually belong to research clusters of more than 4 researchers, thus providing a strong evidence of 
their belonging to scientific groups. Insofar, an important result emerging from this discussion is that the research laboratory doesn't necessarily constitute an appropriate level for analysing scientific collaboration. Indeed, we have, in our typology, stressed the existence of numerous labs for which the frontiers do not fit the reality of collaborative work: laboratories can group several collaboration clusters or spread over several clusters or being part of a cluster.

\section{Conclusion}

Over the last years, there has been an increasing interest in examining the factors influencing academic production. Numerous factors were emphasised both at the individual (age, cohort or gender) and at the collective level (the reciprocal influence of individual characteristics and laboratory reputation, the organization of the laboratory, multidisciplinarity). Nevertheless, if attention has been put at the collective level : it has been largely considered that this collective level corresponds to the level of the laboratories or units of research.

This paper starts from the hypothesis that most quantitative studies in the Economics of Science assume that the collective level of academic production is assimilated to university or laboratory level. We test whether this hypothesis corresponds to the reality of scientific collaboration.

In order to do so, we propose a methodology based on social networks analysis. The application of this methodology allows us to isolate clusters (i.e. parts of networks characterized by a higher collaboration intensity) of diverse characteristics and sizes which may potentially constitute scientific communities. The most important result of our study is that the frontiers of those clusters do not necessarily correspond to the institutional frontiers of research laboratories. Indeed, we stress the existence of several types of laboratories. Those laboratories may correspond to research clusters but, in most cases, they either regroup several clusters or they spread over several clusters or they are parts of clusters. This first result corroborates the relevance of our hypothesis by pointing out the fact that the social reality of academic research doesn't necessarily fit the institutional division of research in laboratories. A closer inspection of those clusters allows us to point out that differences in academic research practices are strongly related to differences in the characteristics and disciplines of research clusters. So, our method seems to provide a promising way for inspecting the social nature of academic research. 
However, this approach only constitutes a first step in quantitative studies of scientific collaboration in academic research. Indeed, although convenient, publications constitute an imperfect measure of scientific collaboration (Katz and Martin, 1997). Our approach must hence be completed with other methods (case studies, etc...), aiming to refine our typology of clusters. Moreover, we were led to eliminate all copublication links with researchers from other universities. This reduced the validity of our analysis since a significant share of researchers of ULP wasn't included in our analysis. Finally, potential communities including researchers from other universities were overlooked. Other extensions of the study could be made by linking our typologies of clusters and laboratories with individual and collective characteristics. For example, we could test whether laboratories split in different groups are more (or less) productive, in term of number of publications, but also patents or number of PhD students, than others labs. We could also look for the individual characteristics of the researchers inside their clusters (are they central or not?) to see if it is link to individual characteristics like age, gender or link to individual scientific productivity.

\section{Bibliography}

Adams, J., Griliches, Zvi. 1996. Measuring science: an exploration. Proceedings of the National Academy of Science vol. 93, pp. 12664- 12670. Allison, Paul D., Long, J.Scott. 1990. Departmental effects on scientific productivity. American Sociological Review. vol. 55. pp. 469-478.

Allison, Paul D., Stewart, John A., 1974. Productivity differences among scientists: evidence for accumulative advantage. American Sociological Review. vol. 39 (August), p. 596-606.

Amin, Amin. Cohendet, Patrick. 2000. Organisational learning and governance through embedded practices, Journal of management and governance, vol. $4, \mathrm{n}^{\circ} 1-2, \mathrm{p} .93-116$.

Bonaccorsi, Andrea. Daraio, Cinzia. 2002. The organization of science. Size, agglomeration and age effects in scientific productivity. In: Proceedings of the Conference "Rethinking Science Policy: Analytical Frameworks for Evidence-based Policy”. SPRU, Brighton, March 21-23. 
Borgatti, Steffen P. Everett, Mark G. Freeman, Linton C. 2002. Ucinet VI for Windows: Software for Social Network Analysis. Harvard: Analytic Technologies.

Borgatti, Steffen P. 1994. How to explain hierarchical clustering. Connections. Vol. 17. n². pp. 78-80.

Brown, John Seely, Duguid, Paul. 1991. Organizationnal learning and communities of practice : toward an unified view of working, learning and innovation. Organization Science, volume 2, n 1. pp. 40-57.

Carayol, Nicolas, Nguyen Thi, Thuc Uyen. 2004. Why do academic scientists engage in interdisciplinary research? Working paper BETA $\mathrm{n}^{\circ} 2004-17$.

Carayol, Nicolas. Matt, Mireille. 2004a. Does research organization influence academic production? laboratory level evidence from a large European university. Research Policy. vol.33. pp. 1081-1102.

Carayol, Nicolas. Matt, Mireille. 2004b. The exploitation of complementarities in scientific production process at the laboratory level. Technovation. Vol.24. pp. 455-465.

Cohendet, Patrick, Llerena, Patrick, 2003, Routines and incentives : the role of communities in the firm. Industrial and Corporate Change, $\mathrm{n}^{\circ} 2$, pp. 271 297.

Cole, Stephen, Cole, Jonathan, 1967. Scientific output and recognition: a study in the operation and reward system in science. American Sociological Review, vol. 32, pp. 377-390.

Cowan, Robin, David, Paul A., Foray, Dominique. 2000. The explicit economics of knowledge codification and tacitness. Industrial and corporate change. vol.9. $\mathrm{n}^{\circ} 2$. p.211-253.

Cowan, Robin. Jonard, Nicolas. 2003. The Workings of Scientific Communities. In Geuna, A, Salter, A \& Steinmueller, E (Ed.), Science and Innovation. Rethinking the rationales for funding and governance Cheltenham: Edward Elgar. (pp. 309-334). 
Dasgupta, Partha. David, Paul A. 1994. Toward a new economics of science. Research Policy. vol.23. pp. 487-521.

David, Paul A. 1998. Clio and the economic organization of science: common agency contracting and the emergence of "Open Science" Institutions. American Economic Association papers and proceedings. American Economic Review. Vol. 88, n². pp. 15-21.

David, Paul A., 1994. Positive feedbacks and research productivity in science : reopening another black box. In: Economics of Technology. Ove Granstrand editor. Amsterdam. Elsevier.

de Solla Price, Derek J. 1963. Little science, big science. New York. Columbia University Press.

Degenne, Alain, Forsé, Michel. 1994. Les réseaux sociaux. Paris. Armand Colin.

Diamond, Arthur M. 1986. The life-cycle research productivity of mathematicians and scientists. The Journal of Gerontology. Vol 41, pp.520525.

Gibbons, Michael, Limoges, Camille, Nowotny, Helga, Schwartzman, Simon, Scott, Peter, Trow, Martin. 1994. The new production of knowledge: the dynamics of science and research in contemporary societies. London. Sage.

Girvan, Michelle, Newman, Mark E.J., 2002, Community structure in social and biological networks, Proceedings of the National Academy of Science of the USA. Vol.99, 7821-7826

Gittelman, Michelle. Kogut, Bruce. 2003. Does good science lead to valuable knowledge? Biotechnology firms and the evolutionary logic of citation patterns. Organization Science. Vol. 49. n4. April. pp. 366-382.

Hussler, Caroline and Rondé, Patrick. The impact of cognitive communities on the diffusion of academic knowledge : evidence from the networks of inventors of a frence university. Research Policy, forthcoming. 
Hussler, Caroline. 2004. Espaces, externalités de connaissance et innovation : éclairages théoriques et empiriques. Unpublished $\mathrm{PhD}$ thesis. University Louis Pasteur - Strasbourg

Johnson, S C. 1967. Hierarchical clustering schemes. Psychometrika. Vol.32. pp. 241-253.

Katz, J. Sylvan, Martin, Ben R. 1997. What is research collaboration? Research Policy. Vol. 26. n¹. pp. 1-18.

Knorr Cetina, Karin. 1981. The Manufacture of Knowledge. Oxford. Pergamon Press.

Knorr Cetina, Karin. 1999. Epistemic Cultures: How the Sciences Make Sense. Chicago. Chicago University Press.

Lerner, Josh and Tirole, Jean. 2000. The simple economics of open source, NBER Working Paper $\mathrm{n}^{\circ} 7600$.

Levin, Sharon G., Stephan, Paula E. 1991. Research productivity over the life cycle: evidence for academic scientists. American Economic Review. Vol. 81. $\mathrm{n}^{\circ} 1$. pp. 114-132.

Levy, Rachel. 2005. Les doctorants Cifre : médiateurs entre laboratoires de recherche universitaires et entreprises. Revue d'Economie Industrielle. Vol 111, pp. 79-96.

Levy, Rachel. 2005. La place de la recherche universitaire dans les systèmes d'innovation : une approche territorialisée. Unpublished $\mathrm{PhD}$ thesis University Louis Pasteur. Strasbourg

Long, J.Scott. McGinnis, Robert. 1981. Organizational context and scientific productivity. American Sociological Review. Vol.46. pp.422-442. Merton, Robert K. 1957. Priorities in scientific discovery: a chapter in the sociology of science. American Sociological Review, vol. 22, $\mathrm{n}^{\circ} 6$, pp.635659

Merton, Robert K. 1968. The Matthew effect in science. Science, Vol.159, n³810, January 5, pp. 56-63. 
Muller, Paul, 2004. Autorité et gouvernance des communautés intensives en connaissances : une application au développement du logiciel libre (Authority and the governance of knowledge intensive communities : an application to the development of open source software). Revue d'Economie Industrielle. $\mathrm{N}^{\circ} 106.2$ nd Trimester. pp. 49-68.

Newman, Mark E.J. 2001. Scientific collaboration networks I. Network construction and fundamental results. Physical Review E. vol. 64. 016131.

Newman, Mark E.J. 2004. Detecting community structure in networks. European Physical Journal B. vol. 38. pp. 321-330.

Newman, Mark E.J. Girvan, Michelle. 2004. Finding and evaluating community structure in networks. Physical Review E. vol. 69. 026113.

Nguyen Thi, Thuc Uyen. 2005. Interdisciplinarité dans un système de recherche universitaire. Unpublished $\mathrm{PhD}$ thesis. Université Louis Pasteur Strasbourg

Nooteboom, Bart. 1999. The triangle : the roles of the go-between. In: S. Gabbay, R. Leenders (editors), Corporate Social Capital and Liability. Dordrecht. Kluwer.pp. 341-355.

Stephan, Paula E. 1996, The economics of science. Journal of Economic Litterature, vol.34, n³. p. 1199-1235.

Stephan, Paula E. 1998. Gender differences in the rewards to publishing in academe: science in the 70's. SEX Roles. vol. 38. pp.11-12.

Turner, Laure, Mairesse, Jacques, 2002. Productivity differences in academic research : an econometric study of french physicists' publications (1980-1997). In: Proceedings of the Conference "Rethinking Science Policy: Analytical Frameworks for Evidence-based Policy”. SPRU, Brighton, March 21-23.

Wasserman, Stanley, Faust, Katherine. 1994. Social Network Analysis: Methods and applications. Cambridge. Cambridge University Press.

Weiss, Yoram. Lillard, Lee A. 1982. Output variability, academic labor contracts, and waiting times for promotion. Research in Labor Economics. vol. 5. pp.157-188. 
Ziman, John, 1997. Disciplinarity and interdisciplinarity in Research. In: proceedings of the Conference "Interdisciplinarity and the organisation of knowledge in Europe", Cambridge, September 24-26. 


\title{
Documents de travail du BETA
}

\author{
2000-01 Hétérogénéité de travailleurs, dualisme et salaire d'efficience. \\ Francesco DE PALMA, janvier 2000. \\ 2000-02 An Algebraic Index Theorem for Non-smooth Economies. \\ Gaël GIRAUD, janvier 2000. \\ 2000-03 Wage Indexation, Central Bank Independence and the Cost of Disinflation. \\ Giuseppe DIANA, janvier 2000. \\ 2000-04 Une analyse cognitive du concept de « vision entrepreneuriale ». \\ Frédéric CRÉPLET, Babak MEHMANPAZIR, février 2000. \\ 2000-05 Common knowledge and consensus with noisy communication. \\ Frédéric KCESSLER, mars 2000. \\ 2000-06 Sunspots and Incomplete Markets with Real Assets. \\ Nadjette LAGUÉCIR, avril 2000. \\ 2000-07 Common Knowledge and Interactive Behaviors : A Survey. \\ Frédéric KCESSLER, mai 2000. \\ 2000-08 Knowledge and Expertise : Toward a Cognitive and Organisational Duality of the Firm. \\ Frédéric CRÉPLET, Olivier DUPOUËT, Francis KERN, Francis MUNIER, mai 2000. \\ 2000-09 Tie-breaking Rules and Informational Cascades : A Note. \\ Frédéric KGESSLER, Anthony ZIEGELMEYER, juin 2000. \\ 2000-10 SPQR : the Four Approaches to Origin-Destination Matrix Estimation for Consideration by the \\ MYSTIC Research Consortium. \\ Marc GAUDRY, juillet 2000. \\ 2000-11 SNUS-2.5, a Multimoment Analysis of Road Demand, Accidents and their Severity in \\ Germany, 1968-1989. \\ Ulrich BLUM, Marc GAUDRY, juillet 2000. \\ 2000-12 On the Inconsistency of the Ordinary Least Squares Estimator for Spatial Autoregressive \\ Processes. \\ Théophile AZOMAHOU, Agénor LAHATTE, septembre 2000. \\ 2000-13 Turning Box-Cox including Quadratic Forms in Regression. \\ Marc GAUDRY, Ulrich BLUM, Tran LIEM, septembre 2000. \\ 2000-14 Pour une approche dialogique du rôle de l'entrepreneur/managerdans l'évolution des PME : \\ I'ISO comme révélateur ... \\ Frédéric CRÉPLET, Blandine LANOUX, septembre 2000. \\ 2000-15 Diversity of innovative strategy as a source of technological performance. \\ Patrick LLERENA, Vanessa OLTRA, octobre 2000. \\ 2000-16 Can we consider the policy instruments as cyclical substitutes ?
}




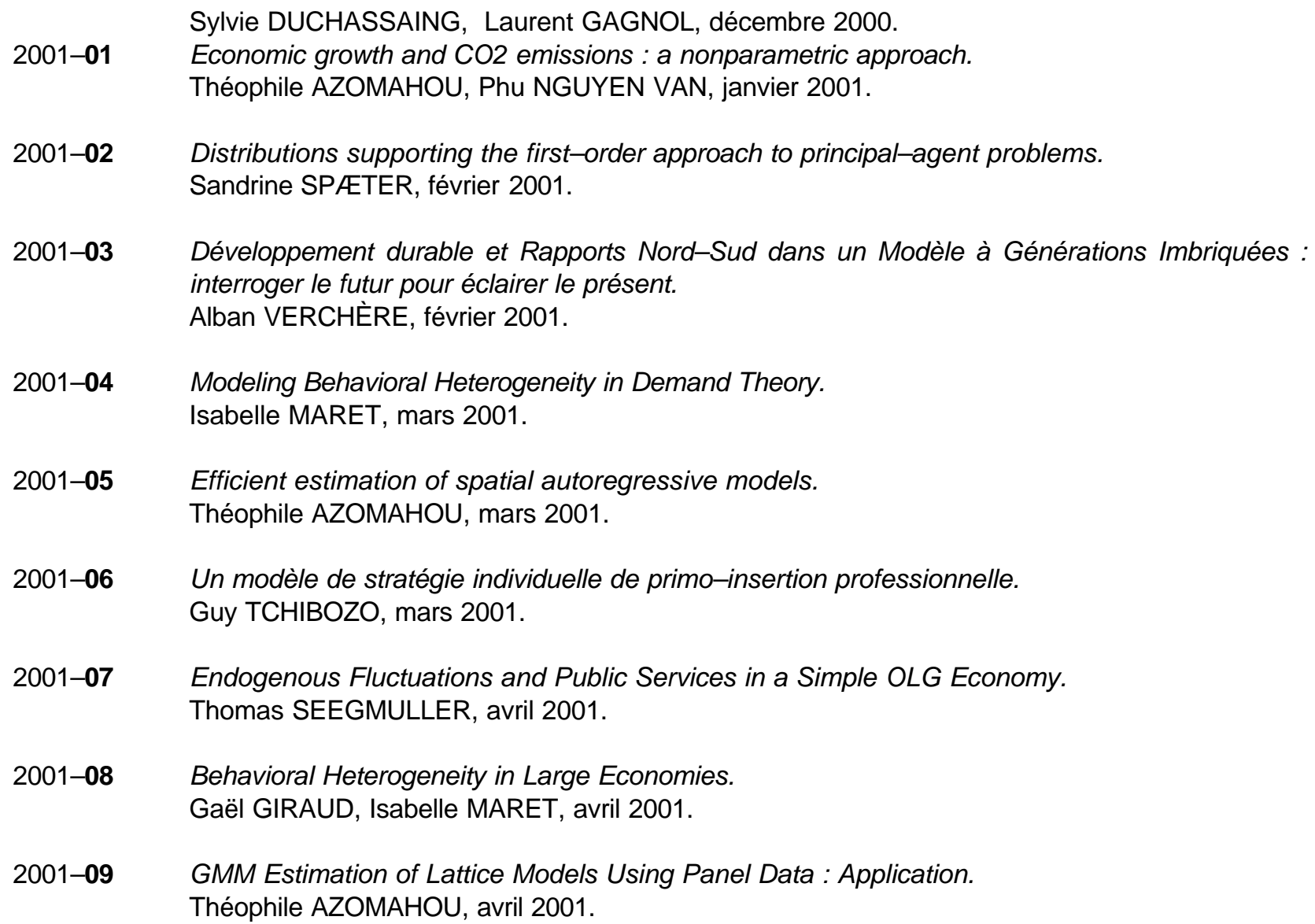

2001-10 Dépendance spatiale sur données de panel : application à la relation Brevets-R\&D au niveau régional. Jalal EL OUARDIGHI, avril 2001.

2001-11 Impact économique régional d'un pôle universitaire : application au cas strasbourgeois. Laurent GAGNOL, Jean-Alain HÉRAUD, mai 2001.

2001-12 Diversity of innovative strategy as a source of technological performance.

Patrick LLERENA, Vanessa OLTRA, mai 2001.

2001-13 La capacité d'innovation dans les regions de l'Union Européenne. Jalal EL OUARDIGHI, juin 2001.

2001-14 Persuasion Games with Higher Order Uncertainty. Frédéric KCESSLER, juin 2001.

2001-15 Analyse empirique des fonctions de production de Bosnie-Herzégovine sur la période 19521989.

Rabija SOMUN, juillet 2001.

2001-16 The Performance of German Firms in the Business-Related Service Sectors : a Dynamic Analysis.

Phu NGUYEN VAN, Ulrich KAISER, François LAISNEY, juillet 2001.

2001-17 Why Central Bank Independence is high and Wage indexation is low. Giuseppe DIANA, septembre 2001.

2001-18 Le mélange des ethnies dans les PME camerounaises: l'émergence d'un modèle d'organisation du travail. 
Raphaël NKAKLEU, octobre 2001.

2001-19 Les déterminants de la GRH des PME camerounaises.

Raphaël NK AKLEU, octobre 2001.

2001-20 Profils d'identité des dirigeants et stratégies de financement dans les PME camerounaises. Raphaël NKAKLEU, octobre 2001.

2001-21 Concurrence Imparfaite, Variabilité du Taux de Marge et Fluctuations Endogènes.

Thomas SEEGMULLER, novembre 2001.

2001-22 Determinants of Environmental and Economic Performance of Firms : An Empirical Analysis of the European Paper Industry.

Théophile AZOMAHOU, Phu NGUYEN VAN et Marcus WAGNER, novembre 2001.

2001-23 The policy mix in a monetary union under alternative policy institutions and asymmetries.

Laurent GAGNOL et Moïse SIDIROPOULOS, décembre 2001.

2001-24 Restrictions on the Autoregressive Parameters of Share Systems with Spatial Dependence. Agénor LAHATTE, décembre 2001.

2002-01 Strategic Knowledge Sharing in Bayesian Games : A General Model. Frédéric KCESSLER, janvier 2002.

2002-02 Strategic Knowledge Sharing in Bayesian Games : Applications.

Frédéric KCESSLER, janvier 2002.

2002-03 Partial Certifiability and Information Precision in a Cournot Game.

Frédéric KCESSLER, janvier 2002.

2002-04 Behavioral Heterogeneity in Large Economies.

Gaël GIRAUD, Isabelle MARET, janvier 2002.

(Version remaniée du Document de Travail n²001-08, avril 2001).

2002-05 Modeling Behavioral Heterogeneity in Demand Theory.

Isabelle MARET, janvier 2002.

(Version remaniée du Document de Travail n²001-04, mars 2001).

2002-06 Déforestation, croissance économique et population : une étude sur données de panel.

Phu NGUYEN VAN, Théophile AZOMAHOU, janvier 2002.

2002-07 Theories of behavior in principal-agent relationships with hidden action.

Claudia KESER, Marc WILLINGER, janvier 2002.

2002-08 Principe de précaution et comportements préventifs des firmes face aux risques environnementaux.

Sandrine SPÆETER, janvier 2002.

2002-09 Endogenous Population and Environmental Quality.

Phu NGUYEN VAN, janvier 2002.

2002-10 Dualité cognitive et organisationnelle de la firme au travers du concept de communauté.

Frédéric CRÉPLET, Olivier DUPOUËT, Francis KERN, Francis MUNIER, février 2002.

2002-11 Comment évaluer l'amélioration du bien-être individuel issue d'une modification de la qualité du service d'élimination des déchets ménagers?

Valentine HEINTZ, février 2002. 
2002-12 The Favorite-Longshot Bias in Sequential Parimutuel Betting with Non-Expected Utility Players.

Frédéric KCESSLER, Anthony ZIEGELMEYER, Marie-Hélène BROIHANNE, février 2002.

2002-13 La sensibilité aux conditions initiales dans les processus individuels de primo-insertion professionnelle : critère et enjeux.

Guy TCHIBOZO, février 2002.

2002-14 Improving the Prevention of Environmental Risks with Convertible Bonds.

André SCHMITT, Sandrine SPFETER, mai 2002.

2002-15 L'altruisme intergénérationnel comme fondement commun de la courbe environnementale à la Kuznets et du développement durable.

Alban VERCHÈRE, mai 2002.

2002-16 Aléa moral et politiques d'audit optimales dans le cadre de la pollution d'origine agricole de l'eau.

Sandrine SPÆETER, Alban VERCHÈRE, juin 2002.

2002-17 Parimutuel Betting under Asymmetric Information.

Frédéric KCESSLER, Anthony ZIEGELMEYER, juin 2002.

2002-18 Pollution as a source of endogenous fluctuations and periodic welfare inequality in OLG economies.

Thomas SEEGMULLER, Alban VERCHÈRE, juin 2002.

2002-19 La demande de grosses coupures et l'économie souterraine.

Gilbert KCENIG, juillet 2002.

2002-20 Efficiency of Nonpoint Source Pollution Instruments with Externality Among Polluters : An Experimental Study.

François COCHARD, Marc WILLINGER, Anastasios XEPAPADEAS, juillet 2002.

2002-21 Taille optimale dans l'industrie du séchage du bois et avantage compétitif du bois-énergie : une modélisation microéconomique.

Alexandre SOKIC, octobre 2002.

2002-22 Modelling Behavioral Heterogeneity.

Gaël GIRAUD, Isabelle MARET, novembre 2002.

2002-23 Le changement organisationnel en PME : quels acteurs pour quels apprentissages ?

Blandine LANOUX, novembre 2002.

2002-24 TECHNOLOGY POLICY AND COOPERATION : An analytical framework for a paradigmatic approach.

Patrick LLERENA, Mireille MATT, novembre 2002.

2003-01 Peut-on parler de délégation dans les PME camerounaises ?

Raphaël NKAKLEU, mars 2003.

2003-02 L'identité organisationnelle et création du capital social : la tontine d'entreprise comme facteur déclenchant dans le contexte africain.

Raphaël NKAKLEU, avril 2003.

2003-03 A semiparametric analysis of determinants of protected area.

Phu NGUYEN VAN, avril 2003. 
2003-04 Strategic Market Games with a Finite Horizon and Incomplete Markets. Gaël GIRAUD et Sonia WEYERS, avril 2003.

2003-05 Exact Homothetic or Cobb-Douglas Behavior Through Aggregation.

Gaël GIRAUD et John K.-H. QUAH, juin 2003.

2003-06 Relativité de la satisfaction dans la vie : une étude sur données de panel.

Théophile AZOMAHOU, Phu NGUYEN VAN, Thi Kim Cuong PHAM, juin 2003.

2003-07 A model of the anchoring effect in dichotomous choice valuation with follow-up. Sandra LECHNER, Anne ROZAN, François LAISNEY, juillet 2003.

2003-08 Central Bank Independence, Speed of Disinflation and the Sacrifice Ratio.

Giuseppe DIANA, Moïse SIDIROPOULOS, juillet 2003.

2003-09 Patents versus ex-post rewards : a new look.

Julien PÉNIN, juillet 2003.

2003-10 Endogenous Spillovers under Cournot Rivalry and Co-opetitive Behaviors.

Isabelle MARET, août 2003.

2003-11 Les propriétés incitatives de l'effet Saint Matthieu dans la compétition académique.

Nicolas CARAYOL, septembre 2003.

2003-12 The 'probleme of problem choice': A model of sequential knowledge production within scientific communities.

Nicolas CARAYOL, Jean-Michel DALLE, septembre 2003.

2003-13 Distribution Dynamics of $\mathrm{CO}_{2}$ Emissions.

Phu NGUYEN VAN, décembre 2003.

2004-01 Utilité relative, politique publique et croissance économique.

Thi Kim Cuong PHAM, janvier 2004.

2004-02 Le management des grands projets de haute technologie vu au travers de la coordination des compétences.

Christophe BELLEVAL, janvier 2004.

2004-03 Pour une approche dialogique du rôle de l'entrepreneur/manager dans l'évolution des PME : I'ISO comme révélateur ...

Frédéric CRÉPLET, Blandine LANOUX, février 2004.

2004-04 Consistent Collusion-Proofness and Correlation in Exchange Economies.

Gaël GIRAUD, Céline ROCHON, février 2004.

2004-05 Generic Efficiency and Collusion-Proofness in Exchange Economies.

Gaël GIRAUD, Céline ROCHON, février 2004.

2004-06 Dualité cognitive et organisationnelle de la firme fondée sur les interactions entre les communautés épistémiques et les communautés de pratique..

Frédéric CRÉPLET, Olivier DUPOUËT, Francis KERN, Francis MUNIER, février 2004.

2004-07 Les Portails d'entreprise: une réponse aux dimensions de l'entreprise "processeur de connaissances ».

Frédéric CRÉPLET, février 2004. 
2004-08 Cumulative Causation and Evolutionary Micro-Founded Technical Change : A Growth Model with Integrated Economies.

Patrick LLERENA, André LORENTZ, février 2004.

2004-09 Les CIFRE : un outil de médiation entre les laboratoires de recherche universitaire et les entreprises.

Rachel LÉVY, avril 2004.

2004-10 On Taxation Pass-Through for a Monopoly Firm.

Rabah AMIR, Isabelle MARET, Michael TROGE, mai 2004.

2004-11 Wealth distribution, endogenous fiscal policy and growth : status-seeking implications.

Thi Kim Cuong PHAM, juin 2004.

2004-12 Semiparametric Analysis of the Regional Convergence Process.

Théophile AZOMAHOU, Jalal EL OUARDIGHI, Phu NGUYEN VAN, Thi Kim Cuong PHAM, Juillet 2004.

2004-13 Les hypothèses de rationalité de l'économie évolutionniste.

Morad DIANI, septembre 2004.

2004-14 Insurance and Financial Hedging of Oil Pollution Risks.

André SCHMITT, Sandrine SPAETER, septembre 2004.

2004-15 Altruisme intergénérationnel, développement durable et équité intergénérationnelle en présence d'agents hétérogènes.

Alban VERCHÈRE, octobre 2004.

2004-16 Du paradoxe libéral-parétien à un concept de métaclassement des préférences.

Herrade IGERSHEIM, novembre 2004.

2004-17 Why do Academic Scientists Engage in Interdisciplinary Research ?

Nicolas CARAYOL, Thuc Uyen NGUYEN THI, décembre 2004.

2005-01 Les collaborations Université Entreprises dans une perspective organisationnelle et cognitive.

Frédéric CRÉPLET, Francis KERN, Véronique SCHAEFFER, janvier 2005.

2005-02 The Exact Insensitivity of Market Budget Shares and the 'Balancing Effect'.

Gaël GIRAUD, Isabelle MARET, janvier 2005.

2005-03 Les modèles de type Mundell-Fleming revisités.

Gilbert KOENIG, janvier 2005.

2005-04 L'État et la cellule familiale sont-ils substituables dans la prise en charge du chômage en Europe ? Une comparaison basée sur le panel européen.

Olivia ECKERT-JAFFE, Isabelle TERRAZ, mars 2005.

2005-05 Environment in an Overlapping Generations Economy with Endogenous Labor Supply : a Dynamic Analysis.

Thomas SEEGMULLER, Alban VERCHÈRE, mars 2005.

2005-06 Is Monetary Union Necessarily Counterproductive?

Giuseppe DIANA, Blandine ZIMMER, mars 2005.

2005-07 Factors Affecting University-Industry R\&D Collaboration : The importance of screening and signalling.

Roberto FONTANA, Aldo GEUNA, Mireille MATT, avril 2005. 
2005-08 Madison-Strasbourg, une analyse comparative de l'enseignement supérieur et de la recherche en France et aux États-Unis à travers l'exemple de deux campus.

Laurent BUISSON, mai 2005.

2005-09 Coordination des négociations salariales en UEM : un rôle majeur pour la BCE.

Blandine ZIMMER, mai 2005.

2005-10 Open knowledge disclosure, incomplete information and collective innovations.

Julien PÉNIN, mai 2005.

2005-11 Science-Technology-Industry Links and the 'European Paradox': Some Notes on the Dynamics of Scientific and Technological Research in Europe.

Giovanni DOSI, Patrick LLERENA, Mauro SYLOS LABINI, juillet 2005.

2005-12 Hedging Strategies and the Financing of the 1992 International Oil Pollution Compensation Fund.

André SCHMITT, Sandrine SPAETER, novembre 2005.

2005-13 Faire émerger la coopération internationale: une approche expérimentale comparée du bilatéralisme et du multilatéralisme.

Stéphane BERTRAND, Kene BOUN MY, Alban VERCHÈRE, novembre 2005.

2005-14 Segregation in Networks.

Giorgio FAGIOLO, Marco VALENTE, Nicolaas J. VRIEND, décembre 2005.

2006-01 Demand and Technology Determinants of Structural Change and Tertiarisation : An InputOutput Structural Decomposition Analysis for four OECD Countries.

Maria SAVONA, André LORENTZ, janvier 2006.

2006-02 A strategic model of complex networks formation.

Nicolas CARAYOL, Pascale ROUX, janvier 2006.

2006-03 Coordination failures in network formation.

Nicolas CARAYOL, Pascale ROUX, Murat YILDIZOGLU, janvier 2006.

2006-04 Real Options Theory for Law Makers.

Marie OBIDZINSKI, Bruno DEFFAINS, janvier 2006.

2006-05 Ressources, compétences et stratégie de la firme: Une discussion de l'opposition entre la vision Porterienne et la vision fondée sur les compétences.

Fernand AMESSE, Arman AVADIKYAN, Patrick COHENDET, janvier 2006.

2006-06 Knowledge Integration and Network Formation.

Müge OZMAN, janvier 2006.

2006-07 Networks and Innovation : A Survey of Empirical Literature.

Müge OZMAN, février 2006.

2006-08 A.K. Sen et J.E. Roemer : une même approche de la responsabilité ? Herrade IGERSHEIM, mars 2006.

2006-09 Efficiency and coordination of fiscal policy in open economies.

Gilbert KOENIG, Irem ZEYNELOGLU, avril 2006.

2006-10 Partial Likelihood Estimation of a Cox Model With Random Effects : an EM Algorithm Based on Penalized Likelihood.

Guillaume HORNY, avril 2006. 
2006-11 Uncertainty of Law and the Legal Process.

Giuseppe DARI-MATTIACCI, Bruno DEFFAINS, avril 2006.

2006-12 Customary versus Technological Advancement Tests. Bruno DEFFAINS, Dominique DEMOUGIN, avril 2006.

2006-13 Institutional Competition, Political Process and Holdup. Bruno DEFFAINS, Dominique DEMOUGIN, avril 2006.

2006-14 How does leadership support the activity of communities of practice? Paul MULLER, avril 2006.

2006-15 Do academic laboratories correspond to scientific communities ? Evidence from a large European university.

Rachel LÉVY, Paul MULLER, mai 2006.

La présente liste ne comprend que les Documents de Travail publiés à partir du fer janvier 2000. La liste complète peut être donnée sur demande.

This list contains the Working Paper writen after January 2000, 1rst. The complet list is available upon request. 